\title{
PROBING STUDENTS' HIGHER ORDER THINKING SKILLS USING PICTORIAL STYLE QUESTIONS
}

\author{
Habiddin Habiddin ${ }^{1 *}$, Elizabeth Mary Page ${ }^{2}$ \\ ${ }^{1}$ Department of Chemistry, Universitas Negeri Malang, Indonesia \\ ${ }^{2}$ Department of Chemistry, The University of Reading, United Kingdom \\ Habiddin_wuni@um.ac.id
}

\begin{abstract}
The ability to use Higher Order Thinking Skills (HOTS) plays a substantial role in determining students' success in future studies. Therefore, it is important that students' ability in this skill is continually refined by training and assessment. This paper explores the responses of first-year university students' to a range of pictorial-style questions in chemical kinetics that require the use of HOTS. 80 food science and 57 chemistry students (137 in total) at The University of Reading (UoR) participated in the study. The results showed that many students demonstrated limited ability to answer HOTS questions. The implications for the teaching of chemical kinetics, particularly at the university level, are discussed.
\end{abstract}

Keywords: pictorial-style questions; higher-order thinking skills (HOTS); chemical kinetics

\section{ИСПИТУВАЊЕ НА СПОСОБНОСТА НА СТУДЕНТИТЕ ЗА РАЗМИСЛУВАЊЕ ОД ПОВИСОК РЕД СО ПРИМЕНА НА ПРАШАЫА БАЗИРАНИ НА ИЛУСТРАТИВЕН ПРИКАЗ}

Примената на способноста за размислување од повисок ред (HOTS) игра важна улога во решавањето на успешноста на студентите во понатамошните студии. Затоа е важно способноста на студентите за овие вештини постојано да се усовршува со вежбање и со проверка. Овој труд ги истражува одговорите на универзитетските студенти од прва година на низа прашања базирани на илустративен приказ од хемиска кинетика, кои бараат примена на HOTS. Во студијата учествуваа 80 студенти по наука за храна и 57 студенти по хемија (вкупно 137) од Универзитетот во Рединг. Резултатите покажаа дека студентите имаат ограничена способност да одговорат на прашањата од HOTS. Се дискутираат импликациите за наставата по хемиска кинетика особено на универзитетско ниво.

Клучни зборови: прашања базирани на илустративен приказ; способност за размислување од повисок ред (HOTS); хемиска кинетика

\section{INTRODUCTION}

Understanding the particulate level or submicroscopic representation of chemical concepts often challenges students to gain a deep knowledge of chemistry [1-5]. The challenges may lead to an unscientific understanding of the relevant concepts [5]. Therefore, the wider chemistry education community agreed that incorporating the chemistry triplet in teaching, including chemistry textbooks [6] as well as in the assessment tool, is timely to improve students' understanding. In addition, portraying chemistry questions in a pictorial style (microscopic and particulate level, graph, picture, and also table) can reveal deep understanding as well as unscientific understanding. Apart from having sound understanding, chemistry teaching and assessment [7] should also be designed to improve students' Higher Order Thinking Skills (HOTS). 
The term 'Higher Order Thinking Skills' (HOTS) refers to a cognitive process which is complex and goes far beyond memorising and recalling facts and information [8] and has a variety of definitions in literature. To date, an agreed single definition of the term has not been established [9]. However, many authors have identified certain criteria to enable a question to be categorised as requiring HOTS. Resnick [10] described several characteristics of a HOTS question, namely that they are non-algorithmic, more complex than the common straightforward question, have multiple solutions, involve judgment and interpretation, require effort to be solved and often involving uncertainty. In the same way, Zohar \& Dori [11] stated that HOTS tasks demand students to develop an argument, construct research questions, make comparisons, solve demanding non-algorithmic tasks, resolve controversies and contradictions and investigate hidden assumptions.

With reference to Bloom's Taxonomy, a HOTS question can be implemented at the comprehension, analysis, synthesis, evaluation, and application levels [12]. In a revised version of Bloom's Taxonomy, HOTS involve apply, analyse, evaluate and create levels of question [13]. Additionally, Newman, as quoted by Lewis \& Smith, [14] stated that a HOTS question requires students to interpret, analyze, or modify information. The emphasis of HOTS in science and chemistry as well as in the engineering curriculum has been of interest due to its capacity to encourage a high-quality leaning environment [15]. For this reason, the educational system in the recent disruptive era is transforming in promoting HOTS [16]. Brookhart [17] stated that HOTS could be reflected with assessing the following aspects including analysis, evaluation and creation; logic and reasoning; judgment; problem-solving; creativity and critical thinking.

Several pieces of literature in science, including chemistry education, uncovered the essential role of teaching and assessment of HOTS [11]. Ghani et al. [16] argued that laboratory activities could not be optimal in building students' conceptual understanding and HOTS skill due to the lack of availability of the assessment's instrument. For this reason, the teaching of chemistry, as well as its assessment at the university level, should promote HOTS [7, 18] and gradually avoid a Lower Order Thinking Skills (LOTS) based teaching and evaluation. Although students with only LOTS can generally gain sufficient marks to pass an examination, they are unable to apply their knowledge to solve a problem requiring HOTS. This phenomenon has been proven in many studies, including [19], in the topic of nomenclature of hydrocarbon compounds.

HOTS, such as critical thinking and problemsolving ability, is essential for future studies and employability where students will be challenged to think deeply and critically. More practice in HOTS questions will also help students become independent and confident learners [18]. Therefore, teachers at all levels are recommended to train students to deal with tasks involving HOTS [11]. Many chemistry educators strongly believe that students' success in basic chemistry modules is mainly influenced by their ability to select relevant information, to problem solve and to apply logical thinking as well as having a positive attitude towards chemistry [20]. Nicoll \& Francisco [20] further explained that success in problem-solving is related to students' ability to apply their knowledge to a new situation, while logical thinking skills are related to students' ability to apply logic and reason when faced with a challenging problem. It has been argued that logical thinking ability rather than mathematical proficiency, is the determining factor of students' success in a physical chemistry course [20].

Ballantyne et al., as quoted by Entwistle [21], point out that one of the roles of university teachers is to foster generic and lifelong skills in their students. Generally, questions posed to students after studying a specific topic are formulaic and follow directly from the notes presented either in lectures or textbooks. They are used to test students' understanding of the topic but usually require the application of a single formula or equation and have only one correct answer. The questions of this type are intended to verify and assess what students have learnt about the topic [22]. Very often traditional teaching and learning at the university-level in chemistry stresses rules, definitions, equations and algorithms, and relies on the terms' knowing', 'remembering', 'defining', identifying', 'understanding' and 'applying'. The ability to deploy such skills is generally sufficient to enable students to pass the course but does not require them to apply knowledge or solve tasks requiring HOTS [23, 24]. It is therefore recommended that chemistry teachers at all levels provide challenging questions to fully evaluate students' understanding. Such questions will encourage students to think creatively and critically.

Several types of instruments have been applied to assess students' HOTS including concept map [16] (the Danczak-Thompson-Overton Chemistry Critical Thinking Test or DOT test) [7], and the 
Science Writing Heuristic (SWH) laboratory approach [25]. According to Brookhart[17] when assessing the HOTS related to problem-solving, particularly in the context of reasoning with data, a pictorial type of question such as a graph or table should be applied. Also, in some studies, the pictorial style question has been implemented to investigate students' HOTS [26, 27]. For this reason, a pictorial style question was used to assess students' HOTS in this study. In particular, this study has taken into consideration the definitions of Resnick, Lewis \& Smith and Zohar \& Dori $[10,11,14]$ as basic judgment to assess students' HOTS regarding chemical kinetics concepts. Information about HOTS of chemistry students will enrich the teaching and learning of chemical kinetics.

\subsection{Aims of the study}

Following our previous study [26] revealing that Indonesian students' HOTS are generally insufficient, this study was similar but involved a group international students. This paper mainly highlights the ability of first-year food science and chemistry students in answering HOTS type of questions.

\section{METHOD}

\subsection{Participants and instrument}

Two groups of students (137 in total) at the University of Reading (UoR), UK, participated in this study, including food science (80) and chemistry (57) students, both in their first year. The criteria of HOTS questions referred to in this study are those explained by Resnick [10] particularly non-algorithmic, involving judgment and uncertainty. For the former group, three chemical kinetics questions (instrument) of a basic pictorial type were used. For the latter group, four chemical kinetics questions of the pictorial type were also applied.In consideration of the different secondary school background between the two groups, the conceptual knowledge required to correctly answer the questions to the two sets of instruments is on a different level. A preliminary survey which was carried out by the chemistry department, at the UoR revealed that chemistry students in general experienced maths and science subjects including a chemistry course in their secondary education while many food science students did not experience maths or chemistry. For this reason, the level of chemical knowledge demanded of the instrument for general chemistry students was higher.
The data were collected at the beginning of the course for the university students before embarking on chemical kinetics teaching. Therefore, their responses are mainly based on the knowledge gained in secondary school. The instrument used in this study was a short-answer test with the emphasis on the pictorial/sub-microscopic level. Using pictorial representations in assessment is highly recommended as such types of instruments are more powerful in uncovering students' unscientific understanding [28]. Feedback on the questions in terms of chemistry content and clarity of language were provided by chemistry staff at the University of Reading before the questions were used for data collection. The time allocated to work on the questions was one and a half hours, but most students finished in one hour.

\subsection{Data analysis}

To uncover students' HOTS, the questions in both sets of instruments were deliberately designed mainly to be HOTS questions with a small proportion of straightforward questions. Students were urged to provide an explanation for their answers to the questions. A HOTS question type is one which is designed specifically in order to stimulate students' critical thinking skills. Meanwhile, a straightforward question is a question that students are more familiar with. Such questions focus on the information students need to know to pass an examination. The addition of a small fraction of straightforward questions was intended to provide a comparison between students' HOTS in terms of the two question categories.

Data were described quantitatively in term of the chemical perspective of students' responses to the questions and how those responses reflect their HOTS ability. To provide a supportive analysis quantitatively, students' responses were classified as Correct Answer (CA), Partially Correct Answer (PCA) and Wrong/No Answer (WNA). CA was attributed to students' responses to a question which was totally correct for both the answer and the explanation to support the answer. PCA was attributed to students' responses to a question which was partially correct (the answer was correct, but the explanation was incorrect and vice versa). For example, a student answered Q1 correctly that the reaction is first order with respect to $\mathrm{NO}_{2}$ and $\mathrm{F}_{2}$. However, the explanation following his/her answer was incorrect. WNA was attributed to students' responses to a question which was totally incorrect for both the answer and the explanation to the answer, or the answer sheet was left blank. 


\section{RESULTS AND DISCUSSION}

\subsection{Description of food science students' responses}

The percentage of food science students who provided CA, PCA and WNA is presented in Table 1. HOTS ability of those students is described according to their responses to the following tasks (chemical kinetics topics).

Table 1

The percentage of food science students' answer to the HOTS question

\begin{tabular}{cccc}
\hline \hline Question & CA (\%) & PCA (\%) & WNA (\%) \\
\hline Q1 & 5.00 & 36.25 & 58.75 \\
Q2 & 3.75 & 48.75 & 47.5 \\
Q3a & 13.75 & 20.00 & 66.25 \\
Q3b & 13.75 & 0 & 86.25 \\
\hline \hline
\end{tabular}

\section{Task 1: Determining rate law using initial rate method}

The purpose of Question 1 was to identify students' HOTS regarding the use of the initial rate method to determine the order of the reaction. For simplification and to distinguish it from Question 1 for chemistry students, Question number1 given to food science students is attributed as Q1F

This question was answered correctly (CA) by only $5 \%$ of students. $36.25 \%$ of students provided a partially correct answer (PCA). Those students with PCA generally only provided the final answer (the order of reactant with respect to $\mathrm{NO}_{2}$ and $\mathrm{F}_{2}$ ) without providing an explanation of how they arrived at it. Meanwhile, the majority of students $(58.75 \%)$ gave the wrong answer or left the answer sheet blank (WNA).

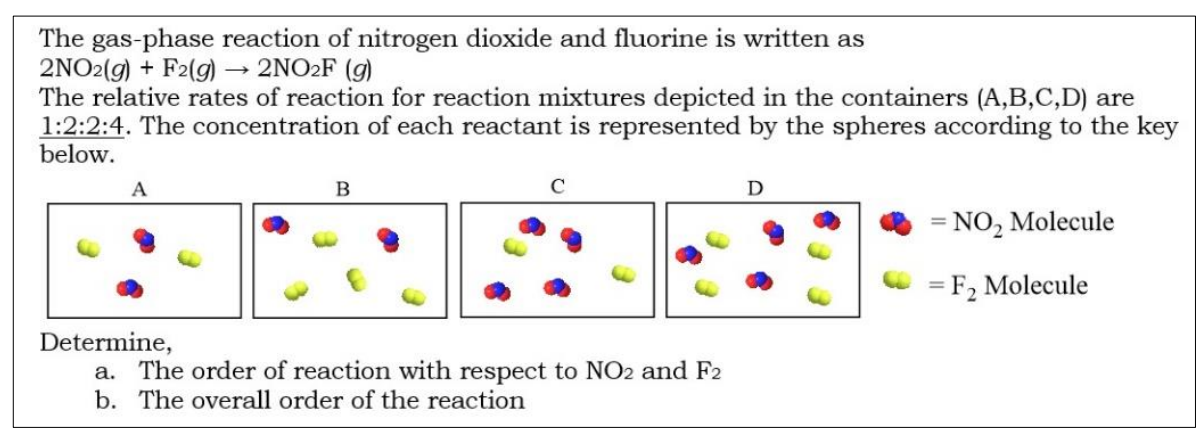

Fig. 1. Q1F to identify HOTS ability of Food science students

In a standard assessment involving an equivalent question to Q1, the question might be provided in the form of numerical type question as retrieved from Whitten [29] and presented in Figure 2 below. Based on the authors experiences, most students are successful in providing a correct answer to this type of question. The difficulty encountered by students in dealing with Q1 confirms how students struggle to solve questions with the same basic concepts presented in a different format [30]. This study also confirms our previous study [28] in which students demonstrated a better ability when answering an algorithmic type question over an equivalent pictorial type one.

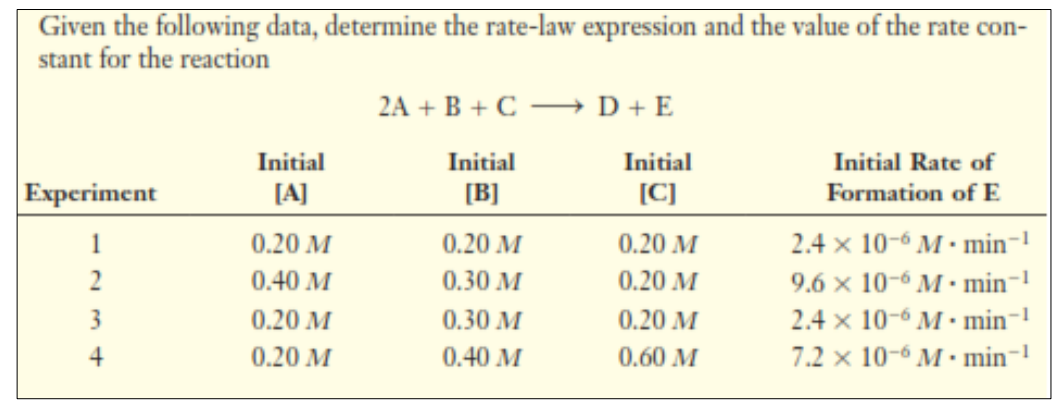

Fig. 2. Example of straightforward question used in common chemistry test 
Task 2: The relationship between concentration and rate of reaction

Question 2 (Q2F) was designed to investigate students HOTS around the concept of rate of reaction and its relationship with concentration or pressure.

The three parts (A, B, and C) in Q2F are based on the same concept, but require different levels of thinking skills in order to solve them. Parts A and B, which are straightforward questions, only need LOTS to be solved. These questions related to the effect of concentration change on reaction rate. Therefore, by memorizing what they have already learned, students should be able to answer these part questions correctly. Meanwhile, part $\mathrm{C}$, which is considered to be the HOTS question, requires critical thinking skills. Even if students understand the relationship between concentration and reaction rate, they still need to decide what the best answer is. The volume increases (concentration decreases) along with an increase in the number of molecules (concentration increases). Students could argue that the rate of reaction could either increase or decrease because the changes (i.e. increases in both volume and number of molecules) would have opposite effects. Because there is no numerical information given, the effect on reaction rate cannot be determined exactly. However, only a small number of students gave such an analytical answer. There is a large difference between the numbers of students who correctly answered the straightforward part question $(48.75 \%)$ and the HOTS question (3.75\%). The similar trend was also uncovered in our previous study [26] involving Indonesian university students $\left(1^{\text {st }}, 2^{\text {nd }}\right.$ and $3^{\text {rd }}$ year chemistry students).

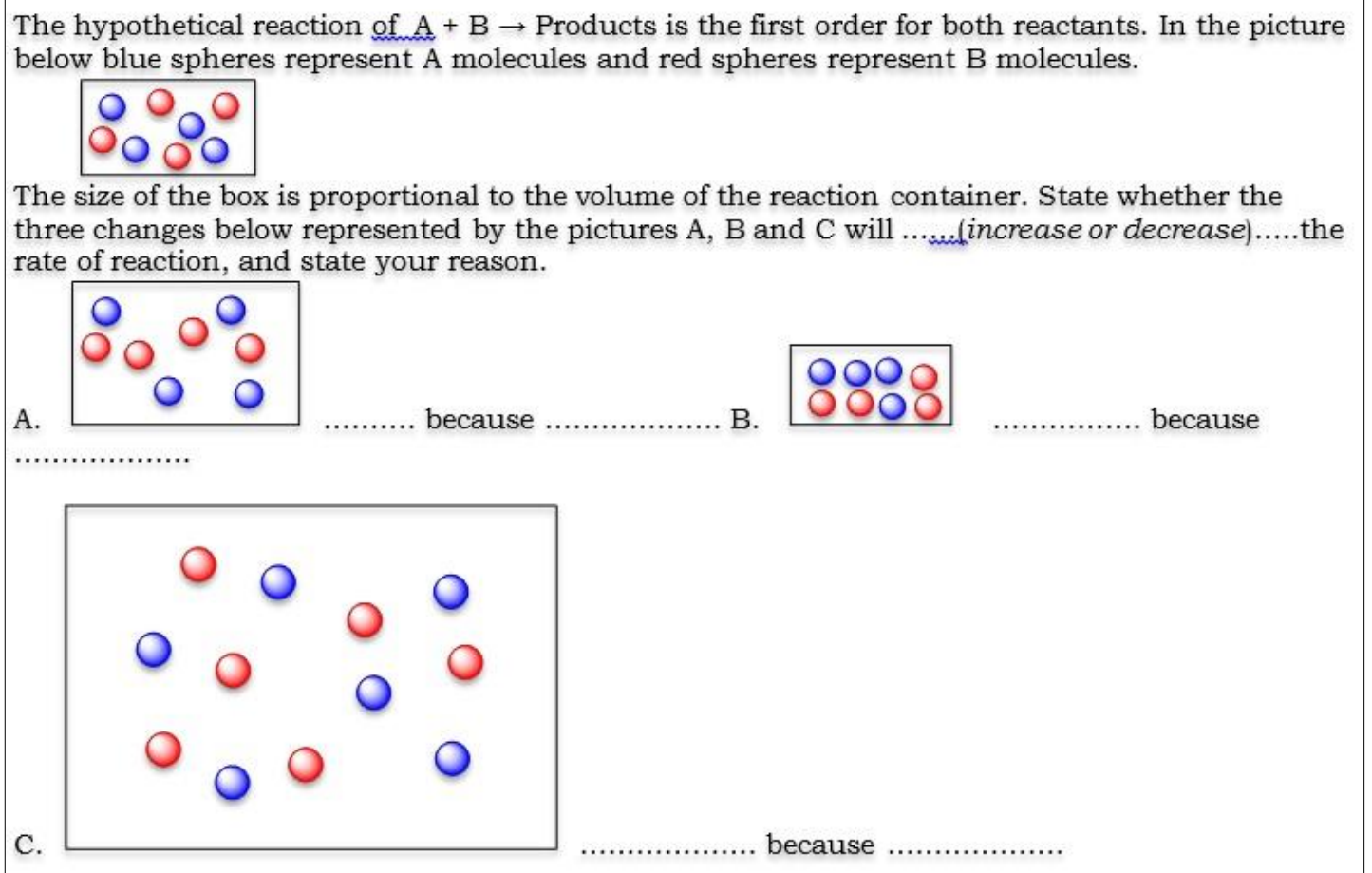

Fig. 3. Q2F to identify HOTS ability of Food science students

\section{Task 3: Rate constant}

In order to investigate students' HOTS in relation to the determination of the rate constant, a question presented in microscopic representation is provided in Question $3(\mathrm{Q} 3 \mathrm{~F})$ below.

Both parts A and B require HOTS in order to be solved. The number of students who gave the correct answer (CA) for both parts in this question is almost the same (13.75\% and $20 \%)$, but the number of students who gave the partially correct answer (PCA) significantly different. $13.75 \%$ students gave PCA for part (b) and $0 \%$ for part (a). These results confirm that students' HOTS are inadequate to answer an analytical question. This finding is in line with our previous work [26]. 


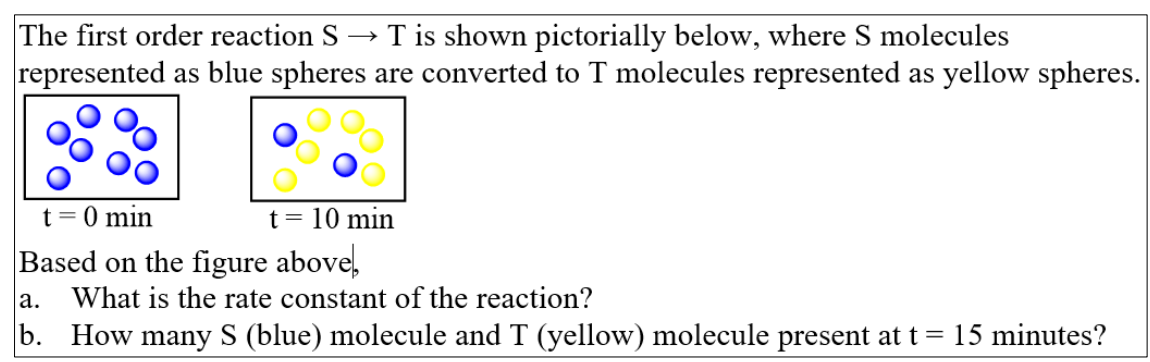

Fig. 4. Q3F to identify HOTS ability of Food science students

\subsection{Description of chemistry students' responses}

The percentage of chemistry students who provided CA, PCA and WNA is presented in Table 2 below. HOTS ability of those students is described according to their responses to the following tasks.

\section{Table 2}

The percentage of chemistry students' answer to the HOTS question

\begin{tabular}{cccc}
\hline \hline Question & CA (\%) & PCA (\%) & WNA (\%) \\
\hline Q1 & 8.93 & 44.6 & 46.4 \\
Q2 & 1.79 & 41.1 & 57.1 \\
Q3 & 8.93 & 33.9 & 57.1 \\
Q4 & 5.36 & 25 & 69.6 \\
\hline \hline
\end{tabular}

\section{Task 1: The relative rates and half-life} of the first-order reaction

This task is represented by question number 1 below. For simplification and to differentiate it from Question 1 for food science students, Question 1 for chemistry students is numbered Q1C. This question is given in four parts ( $a, b, c$ and d) and depicts three different numbers of $\mathrm{N}_{2} \mathrm{O}_{5}$ molecules placed in three equal-volume containers at the same temperature. Part (a) focusses on students' understanding of the relative reaction rates in these three containers and how they depend on the starting concentration; part (b) concern with the way the relative rates would be affected if the volume of each container were doubled; part (c) investigates how the actual rates would be affected if the volume of each container were doubled and part (d) investigates the relative half-lives of the reactions in (i) to (iii). The result shows that only $8.93 \%$ of students gave CA, $44.60 \%$ gave PCA, and $46.40 \%$ gave WNA.

In part (a), students are expected to understand that for a reaction that follows first-order kinetics, the rate will be directly proportional to the reactant concentration. In this case, Rate $=k[\mathrm{X}]$. Because the containers are equal volume and the rate constants $(k)$ are the same, students can use the number of molecules to represent the concentration. Almost all students with CA and PCA answered this question correctly.

In part (b), students are expected to be aware that doubling the volume of each container will have no effect on the relative rates of reaction compared to part (a). Doubling the volume would halve each of the concentrations, but the ratio of the concentrations for containers (i) - (iii) would still be $5: 2: 4$. Therefore, the relative rates in the three containers would remain the same. Generally, students with CA and PCA showed their good attempts to answer the question correctly. However, a fraction of students with PCA showed their misunderstanding in this part, as shown in Figure 6.

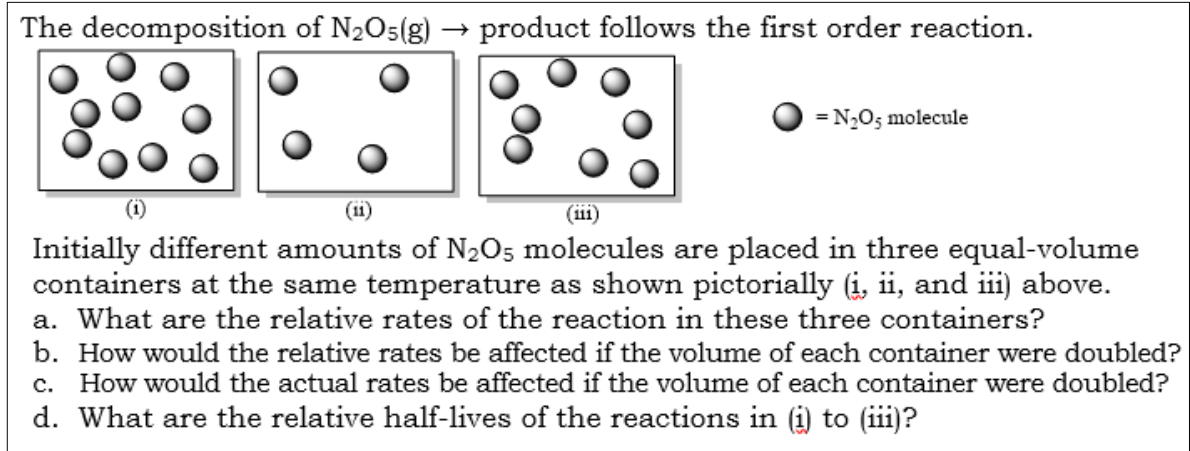

Fig. 5. Q1C to identify HOTS ability of chemistry students 


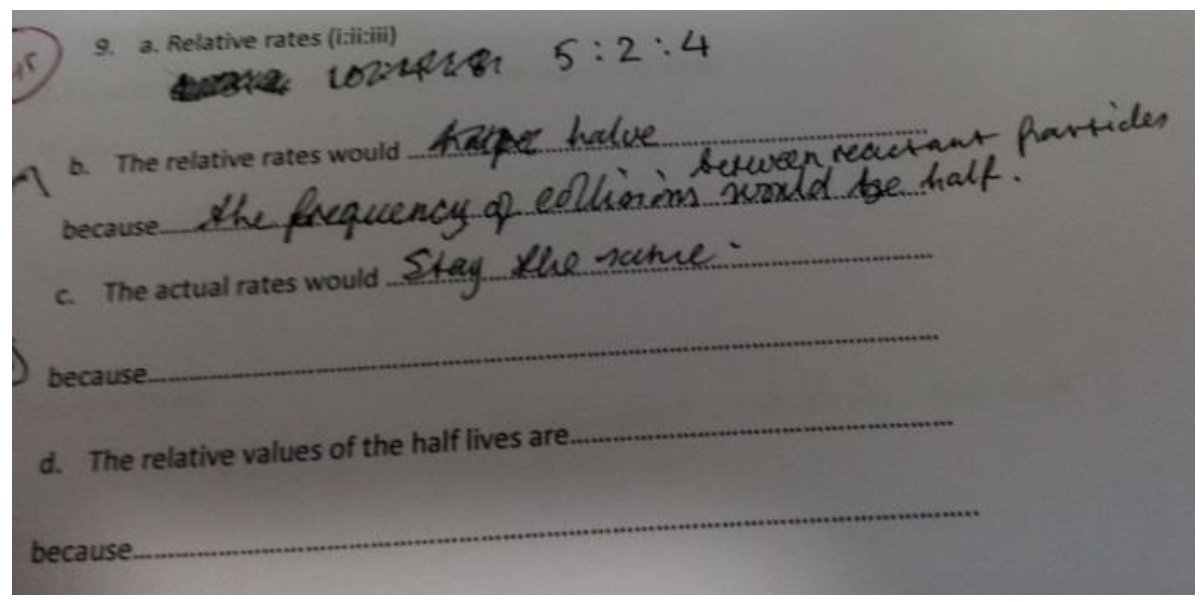

Fig. 6. Typical misunderstanding of Q1C

This student believes that doubling the volume of all containers will decrease the relative rates by half. Even though the reason that he/she provided is scientifically acceptable, the decrease in a number of collisions happens in all of the containers equally, so the relative rates in the three containers would remain the same.

In part (c), students are expected to understand that the actual (absolute) rate for all containers would decrease by $50 \%$. Generally, students with
CA could explain that the rate in all containers will decrease by half, while students with PCA as shown in Figure 7 mostly could only explain that the rates will decrease without mentioning they would decrease by $50 \%$. In addition, students with CA explained the decrease in rate as a result of the increase in concentration that led to a decrease in the frequency of collision. This explanation is similar to students with the PCA explanations as portrayed in Figure 7.

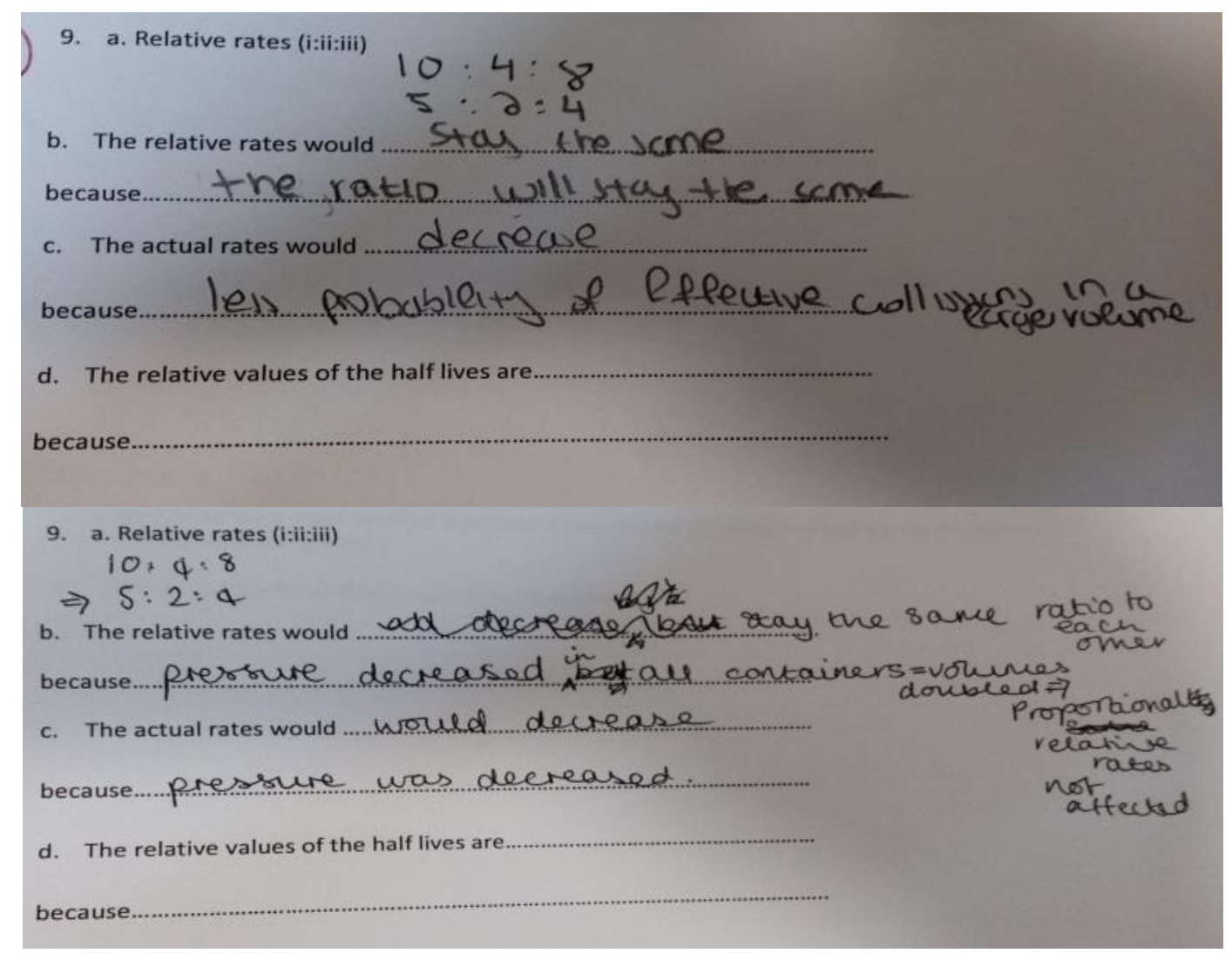

Fig. 7. Examples of the students' PCA for Q1C 
In part (d) students are expected to comprehend that for a first-order reaction, the half-life is independent of the initial concentration of the reactant. Therefore, the half-lives for containers (i), (ii) and (iii), will be the same. This question was only answered correctly by students with CA, while students with PCA left their answer sheets blank. In our previous study [26], CA was only provided by some of the third-year students.

Task 2: Determining the reaction order based on the time needed for initial concentration to drop by a half

This task is represented by question number 2 (Q2C) below. This question is in two parts (a and b) and depicts three changes in concentration for a reaction with increasing time. Part (a) asks students to determine whether the reaction is first-order or second-order, while part (b) asks students to calculate the rate constant for the reaction.

In Q2C.a, students were expected to find the number of $\mathrm{X}$ atoms at $t=0 \mathrm{~min}$ and the number of $\mathrm{X}$ atoms remaining and $\mathrm{X}_{2}$ molecules formed at the following times; $t=10 \mathrm{~min}$ and $t=20 \mathrm{~min}$. By understanding that concentration of $\mathrm{X}$ atoms are halved at $t=10 \mathrm{~min}$ and is halved again at $t=20$ min, students should understand that the half-life is independent of the concentration of the reactant, X, and hence the reaction is first-order in X. In addition, Q2C.b asks students to calculate the rate constant of the reaction. The result shows that only 1.79 $\%$ of students show CA, $41.10 \%$ of students show PCA and $57.10 \%$ of them show WNA.

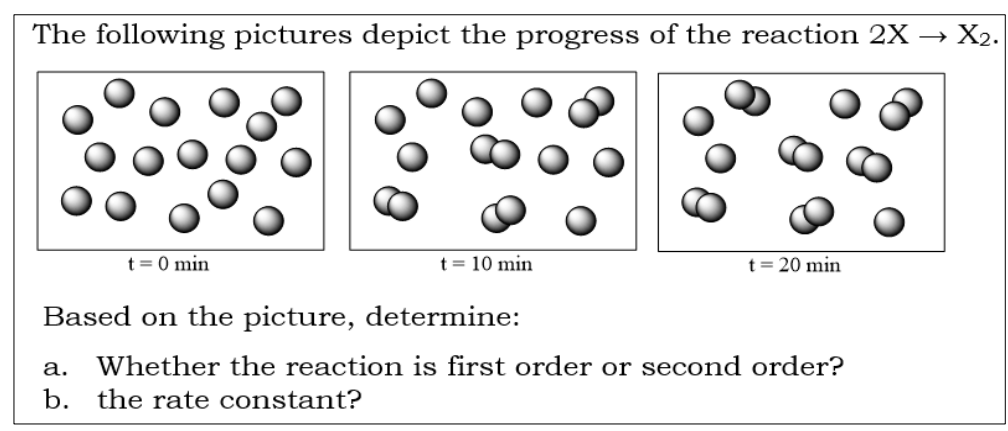

Fig. 8. Q2C to identify HOTS ability of chemistry students
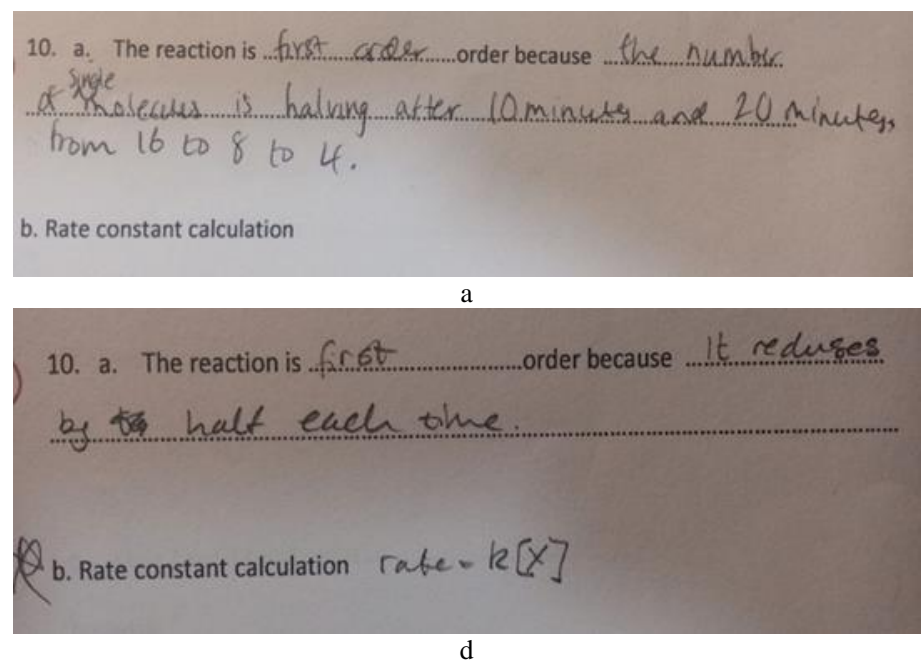
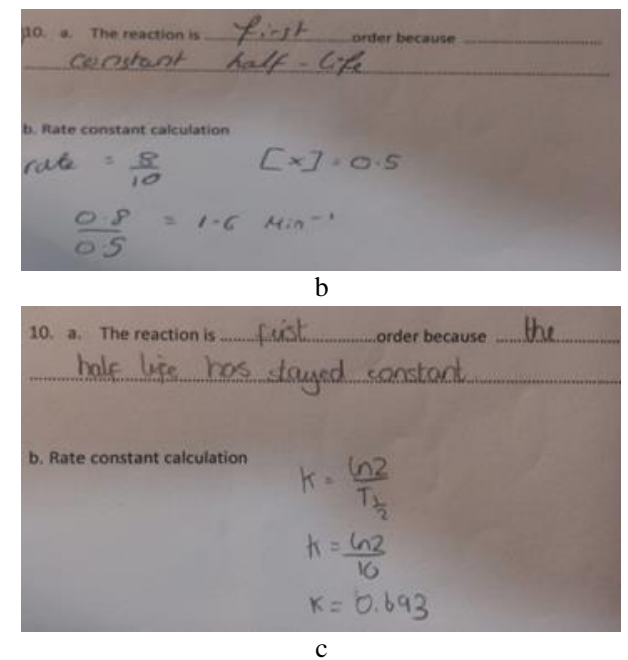

Fig. 9. Examples of the students' PCA for Q2C

Almost all students with CA and PCA understand that because the time needed for the concentration to be halved is constant, during each10 minutes interval, this reaction should be first-order. Students with PCA fail in solving the following question in which they were expected to implement the equation $k=\frac{\ln 2}{t_{1 / 2}}$. Generally, they left the question blank, as shown in Figure 9(a). Meanwhile, some students showed how they struggled to solve question part (b) as represented by Figure 9(b). Ac- 
tually, part (b) is a familiar type of question for students. However, to solve this question correctly, students needed to find out the order of the reaction. Therefore, many students failed in this question as well. This fact confirms that students' HOTS is inadequate. Students' answers indicate that they could not obtain the information about the half-life, $t^{1 / 2}$, of the reaction. Because of this difficulty, students tended to choose the equation Rate $=k[\mathrm{X}]$ as shown in Figure 9(d). A small fraction of students actually understood that the half-life of this reaction is 10 minutes. However, some of them failed in carrying out the mathematical operation, as shown in Figure 9(c). This confirms that it is often the mathematical ability that causes students to make an error, but it could also be explained by carelessness. In addition, the student omitted to provide the unit of $k$ in his/her answer. This phenomenon is often found among students implying they only focus on doing the calculation without realising that the unit is also important. This lack of awareness may lead to difficulties in converting between units. It was found that even a prospective teacher encountered difficulty in doing unit conversions [31].

\section{Task 3: Reaction mechanism, intermediate and} catalyst

The topics are represented is represented by question number $3(\mathrm{Q} 3 \mathrm{C})$. This question is in three parts $(\mathrm{a}, \mathrm{b}$ and $\mathrm{c})$ and depicts an imaginary two-step mechanism. In part (a), students are expected to write the equation for the net reaction, while in the next two parts, students are asked to identify the intermediate and catalyst. In part (a), students are expected to work out that the picture shows a reaction with a two-step mechanism as follow.

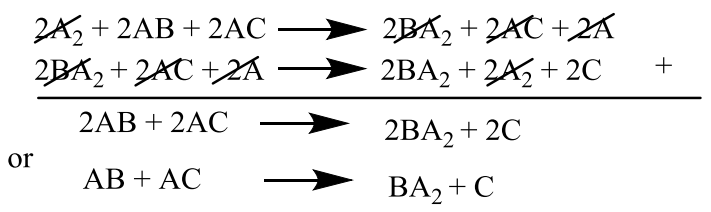

In part (b), students are expected to work out that $\mathrm{A}$ is an intermediate because $\mathrm{A}$ is formed in one elementary reaction and consumed in the next. They are also expected to work out that $\mathrm{A}_{2}$ is a catalyst because a catalyst is a substance that changes the speed of a chemical reaction without undergoing a permanent chemical change itself. In this reaction, $\mathrm{A}_{2}$ is reformed as the last product.

The result shows that only $8.93 \%$ of students show CA, while $33.90 \%$ and $57.10 \%$ show PCA and WNA, respectively. Some students with CA provided a scientific explanation that was not always better than the explanation provided by students with PCA. In explaining why $\mathrm{A}_{2}$ is the catalyst in this reaction, CA student stated that it is in first and the last step, and is not used up in the reaction. Meanwhile, some PCA students provide a better explanation with an emphasis on "regenerated".

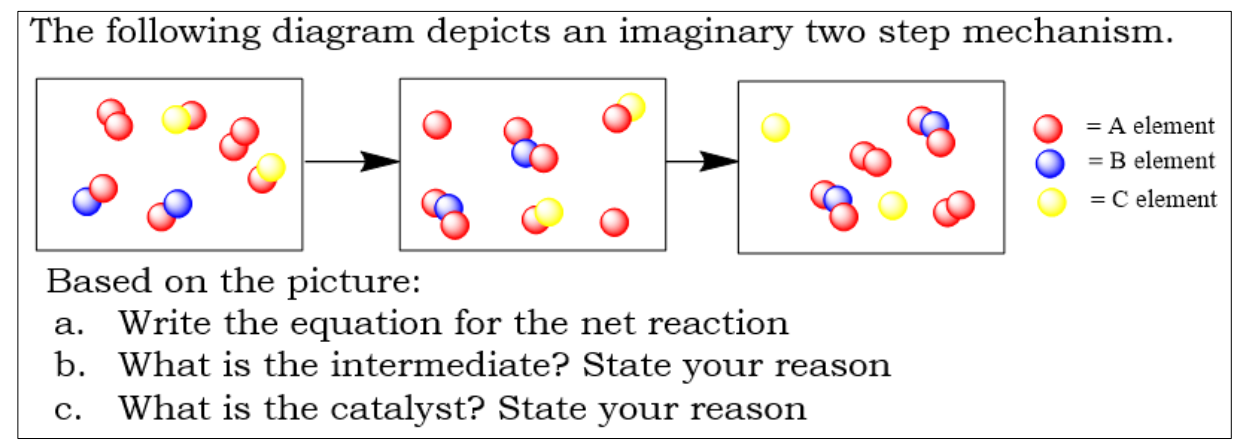

Fig. 10. Q3C to identify HOTS ability of chemistry students

In this question, students with PCA generally struggled as to how to write the net equation from the microscopic representation provided. As shown in Figure 11, none of the PCA students could identify that there are two steps in the mechanism of this reaction. In addition, determining the substance that acts as an intermediate is another challenge for students. One student chose AC as the intermediate with his/her reason being that "AC is not in the product". Despite the fact that an intermediate does not exist in the final product, but not all reactants that are used up in a reaction are always intermediates. For this reason, this student understanding can be categorized as a typical misunderstanding/misconception. This kind of misunderstanding is a novel finding in the chemical kinetics area. A comprehen- 
sive review around teaching and learning in chemical kinetics carried out by Bain \& Town [32] covering plenty published works in several mainstream chemistry and science education journals also did not reveal this typical misunderstanding.

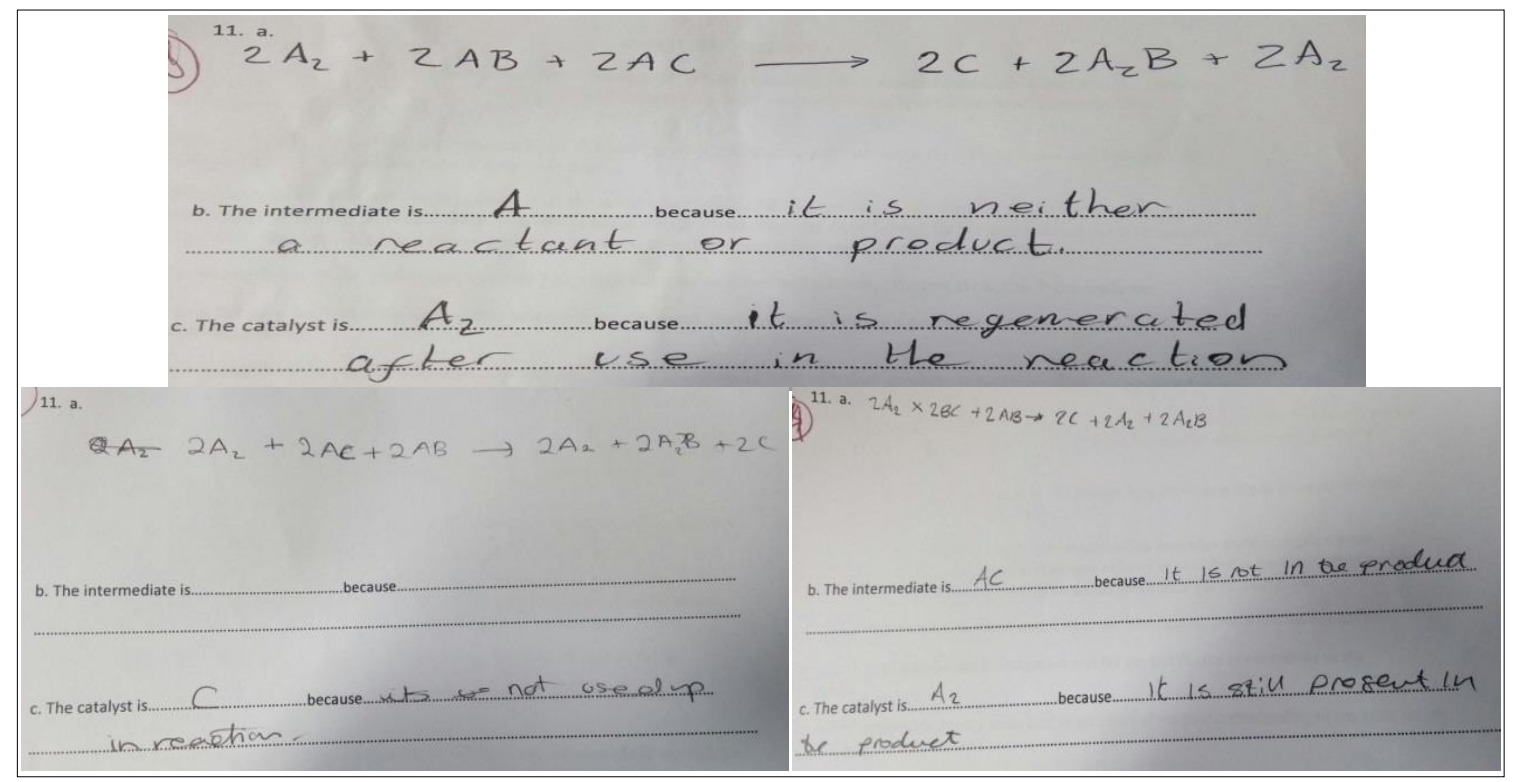

Fig. 11. Examples of students' PCA for Q3C

Task 4: Determining the time needed for reactants with different reaction orders to be halved

This task is represented by question number 4 (Q4C). This question depicts a microscopic representation of decomposition of nitrogen dioxide to nitric oxide and oxygen at a certain temperature
$2 \mathrm{NO}_{2}(\mathrm{~g}) \rightarrow 2 \mathrm{NO}(\mathrm{g})+\mathrm{O}_{2}(\mathrm{~g})$. The second box represents the situation after the first half-life of the reaction, and the last box represents the situation after the second half-life. Furthermore, students are expected to determine the time taken to reach the final situation if the reaction is (a) zero, (b) first or (c) second order.

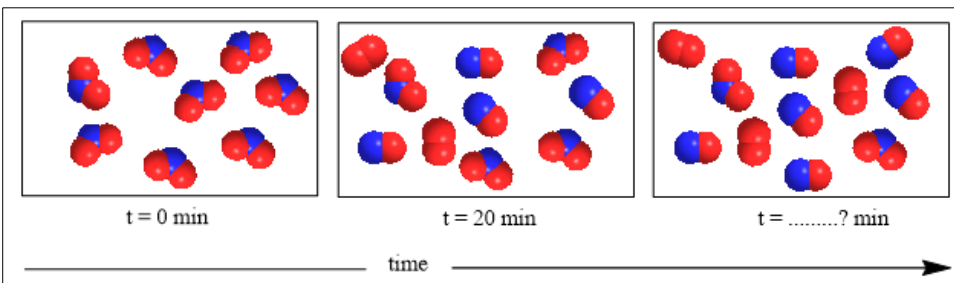

Determine the time for the final representation above if the reaction is
a. zero order
b. first order
c. second order

Fig. 12. Q4C to identify HOTS ability of chemistry students

In this question, students are expected to use their knowledge to predict the time needed for the concentration of a reactant to be halved dependent on its reaction order. In part (a), students should know that for zero-order kinetics, $t_{2}^{1}=\frac{[A]_{0}}{2 k}$; the half-life is directly related to the initial concentration. So, if this reaction was zero-order, then the second half-life would decrease from $20 \mathrm{~min}$ to $10 \mathrm{~min}$.
The time to reach the condition depicted in the box (c) will therefore be $20+10=30 \mathrm{~min}$. For first-order kinetics, $t_{2}^{1}=0.693 / \mathrm{k}$; the half-life is constant because it depends only on the rate constant and not on the reactant concentration. Therefore, two halflives will be $20+20=40$ minutes. Furthermore, for second-order kinetics, $t_{2}^{1}=\frac{1}{k[A]_{0}}$; the half-life for a second-order reaction is inversely proportional to 
the initial concentration. Consequently, each halflife for a second-order reaction is twice as long as the preceding one. So, if the first half-life is 20 minutes, the second half-life will be 40 minutes. Therefore, the time to reach the condition depicted in the box (c) will be $20+40=60$ minutes.

The result shows that only $5.36 \%$ of students perform CA, while $25 \%$ and $69.60 \%$ of them perform PCA and WNA respectively. Students' difficulties in this task are confirmed by the large number of students who left the question unanswered. A typical misunderstanding uncovered is that students use the equation for the half-life of a first-order reaction to find out the half-life of a zero-order reaction and do not realise that they are different.

In addition, even students with CA provided imperfect explanations. A student gave the correct answer to question (a), i.e. that the time to reach the condition depicted in the box (c) will be 30 minutes. However, his/her explanation that "constant decrease in reactants" is confusing. The amount of reactant concentration decreases when reaching its half-life is always constant (half of its initial concentration) in any order of the reaction.

A similarly confusing explanation was provided by students with PCA. He/she argued that if the reaction is a zero-order, the time taken is 30 minutes because "the same time is taken for each molecule to react". This reason is unacceptable because the half-life for a zero-order reaction is directly related to the initial concentration. This student seems to explain that the time taken for the concentration of a reactant to be halved is always constant. It indicates that the student got into difficulty in differentiating the difference between the halflife in a zero-order and a first-order reaction. This finding confirms the previous study that students often applied a first-order reaction equation and reasoning to deal with a zero-order kinetic prompt [33].

The task that is considered the easiest of the three is determining the time in a first-order reaction. Almost all students with CA and PCA confirm that the half-life of a first-order reaction is constant because it depends only on the rate constant and not on the reactant concentration. It seems that generally, students are familiar with the first-order reaction than any other order. Many chemistry textbooks provide a complete explanation of this order. Besides, some exercises in chemical kinetics are generally dominated by first-order reactions. In addition, radioactive decay is a first-order reaction, and this is often used as an example. Therefore, stu- dents' familiarity with this subtopic is not surprising. Therefore, equal emphasis on all reaction orders is recommended.

\subsection{The implication for chemistry teaching}

The results of this study provide several insights to be taken into account when delivering chemistry teaching. Also, chemistry textbooks and the curriculum should adopt and consider empirical and research evidence in order to provide rigorous chemistry teaching. Many pieces of literature in the area of HOTS only pointed out the inadequate skills of students in dealing with HOTS questions making the assumption that this lack of proficiency is due to the students. We suggest that chemistry teaching and assessment applied in chemistry classes, as well as educational policy regarding chemistry curriculum, may contribute greatly to this issue. Gilbert [34] stated that the overload of chemistry content in the curriculum which covers much factual information is a root of difficulty for students when linking information. Therefore, they often got into difficulty when applying a concept he/she had learned to a different context [30].

That student often wrongly applied first-order kinetic approach to solving non-first-order kinetics, could be rooted in the fact that some textbooks in basic chemistry [35-38] allocate more pages for the discussion of first-order reactions than other reaction orders. Also, the concept of first-order kinetics is also met in the discussion of radioactive decay. These phenomena increase the familiarity of students to the first-order concept over other reaction orders. This is strengthened by Bain et al. [33] that student applied the first-order integrated law to solve a zero-order prompt. This infers that his/her problemsolving ability (part of HOTS aspects) in answering a zero-order kinetic question was diverted by his/her knowledge on first-order kinetics [33]. Therefore, it is highly recommended that chemistry educators devote attention to make sure that his/her students understand the basic three reaction orders well and avoid confusing the characteristics of different orders.

Students' difficulty in solving questions requiring HOTS could be caused by two possible factors. Firstly, some chemistry teaching may not be delivered in a way to improve students HOTS ability. Rather, supplying huge information in order to prepare students to pass an examination is the prime goal. Therefore, it is recommended to deliver a HOTS based chemistry teaching because it has a big influence on building students' HOTS [30]. Active learning strategies such as inquiry [39] is a promis- 
ing exercise to promote HOTS. Secondly, the assessment procedure may mostly be designed with the purpose of only evaluating students' ability to pass an examination. HOTS-based assessment should always be applied as this will train students' HOTS ability $[11,18,30]$. Familiarity in practice with the type of assessment demanding HOTS contributes to students in two ways; one is storing information in long term memory rather than in the short term one and the other is acquiring a deep conceptual understanding [40]. We also suggest that all teaching instruments, including textbooks, worksheet and learning media should be designed to encourage building students' HOTS ability. Teaching instruments, including assessment tools purposely designed to improve HOTS, have the potential to promote HOTS [13].

\section{CONCLUSIONS}

This study shows that Food Science students' ability regarding HOTS question is quite low. In all three questions, the number of students gave the correct answer (CA) is very low. Some students provided a partially correct answer (PCA). Meanwhile, the number of students giving a wrong/no answer (WNA) is always the highest. This suggests that students should be trained to become familiar with such HOTS-type questions. This same trend is also shown by chemistry students. The proportion of students with WNA is also highest among chemistry students.

This study suggests that students' HOTS must be promoted in all aspects of chemistry teaching and learning. For this purpose, Zohar \& Dori [11] emphasised that students must be frequently given HOTS tasks. Chemistry teaching and learning strategy also can contribute to promoting students' HOTS. For instance, an active learning strategy can improve student' critical thinking [41]. Mathematical ability was also a cause of some students' mistakes in answering questions. Frequently, students understand the concept but make errors due to incorrect mathematical operation. In other case, students tend to use a numerical operation to solve even a simple conceptual question.

\subsection{Limitation of the study}

This study was conducted before students embarking chemical kinetics teaching in their university class. Students' responses were mostly based on their knowledge and experience from secondary school chemistry. Therefore, the results may not be fully transferable to represent first-year university students. The results of this study also do not comparable to our previous study involving Indonesian chemistry students $\left(1^{\text {st }}\right.$ to $3^{\text {rd }}$ years) who have been experienced chemical kinetics teaching at the university level. However, these results can be used as evidence to encourage a HOTS-based teaching approach in chemical kinetics both at the secondary and tertiary levels.

Acknowledgements. We thank The Directorate General of Higher Education, Ministry of Research, Technology, and Higher Education, The Republic of Indonesia for the Ph.D. scholarship of one of us (Habiddin).

\section{REFERENCES}

[1] V. F. Savec, K. S. W. Grm, Development of chemistry preservice teachers during practical pedagogical training: selfevaluation vs. evaluation by school mentors, Acta Chim. Slov., vol. 64, no. 1, pp. 63-72 (2017).

[2] A. L. Chandrasegaran, D. F. Treagust, B. G. Waldrip, A. Chandrasegaran, Students' dilemmas in reaction stoichiometry problem solving: deducing the limiting reagent in chemical reactions, Chem. Educ. Res. Pract., vol. 10, no. 1, pp. 14-23 (2009). DOI: 10.1039/B901456J

[3] K. S. Taber, Building The Structural Concepts of Chemistry: Some Considerations From Educational Research, Chem. Educ. Res. Pract., vol. 2, no. 2, pp. 123158 (2001). DOI: 10.1039/B1RP90014E

[4] I. Kermen, M. Méheut, Different models used to interpret chemical changes: analysis of a curriculum and its impact on French students' reasoning, Chem. Educ. Res. Pract., vol. 10, no. 1, pp. 24-34 (2009). DOI: $10.1039 / \mathrm{B} 901457 \mathrm{H}$.

[5] A. L. Chandrasegaran, D. F. Treagust, M. Mocerino, An evaluation of a teaching intervention to promote students' ability to use multiple levels of representation when describing and explaining chemical reactions, Res. Sci. Educ., vol. 38, no. 2, pp. 237-248 (2008). DOI: $10.1007 / \mathrm{s} 11165-007-9046-9$

[6] J. E. Upahi, U. Ramnarain, Representations of chemical phenomena in secondary school chemistry textbooks, Chem. Educ. Res. Pract., vol. 20, no. 1, pp. 146-159, 2019. DOI: 10.1039/C8RP00191J

[7] S. M. Danczak, C. D. Thompson, T. L. Overton, Development and validation of an instrument to measure undergraduate chemistry students' critical thinking skills, Chem. Educ. Res. Pract., vol. 21, no. 1, pp. 62-78, 2020. DOI: $10.1039 / \mathrm{c} 8 \mathrm{rp} 00130 \mathrm{~h}$

[8] A. Phakiti, Assessing higher-order thinking skills in language learning, The TESOL Encyclopedia of English Language Teaching, pp. 1-7, 18-Jan-2018. DOI:10.1002/9781118784235.eelt0380.

[9] A. Zohar, Elements of teachers' pedagogical knowledge regarding instruction of higher order thinking, J. Sci. Teacher Educ., vol. 15, no. 4, pp. 293-312 (2004). DOI: 10.1023/B:JSTE.0000048332.39591.e3.

[10] L. B. Resnick, Education and Learning to Think. Washington, National Academy Press, 1987.

[11] A. Zohar, Y. J. Dori, Higher order thinking skills and lowachieving students: are they mutually exclusive?, $J$. 
Learn. Sci., vol. 12, no. 3, pp. 145-181 (2003). DOI: $10.1207 / \mathrm{S} 15327809 J L S 1202 \_1$

[12] D. McLoughlin, J. Mynard, An analysis of higher order thinking in online discussions, Innov. Educ. Teach. Int. vol. 46, no. 2, pp. 147-160 (2009).

[13] V. Paideya, R. Sookrajh, Exploring the use of supplemental instruction: Supporting deep understanding and higher-order thinking in chemistry, South African $J$. High. Educ., vol. 24, no. 5, pp. 758-770 (2010).

[14] A. Lewis, D. Smith, Defining Higher Order Thinking, Theory Pract., vol. 32, no. 3, pp. 131-137 (1993).

[15] S. Toledo, J. M. Dubas, Encouraging higher-order thinking in general chemistry by scaffolding student learning using marzano's taxonomy, J. Chem. Educ., vol. 93, no. 1, pp. 64-69 (2016).

DOI: $10.1021 /$ acs.jchemed.5b00184.

[16] I. B. A. Ghani, N. H. Ibrahim, N. A. Yahaya, J. Surif, Enhancing students' HOTS in laboratory educational activity by using concept map as an alternative assessment tool, Chem. Educ. Res. Pract., vol. 18, no. 4, pp. 849-874 (2017). DOI: 10.1039/C7RP00120G.

[17] S. M. Brookhart, How to Assess Higher Order Thinking Skills in Your Classroom. Virginia, Alexandria, 2010.

[18] G. Tsaparlis, U. Zoller, M. Fastow, A. Lubezky, Students' self-assessment in chemistry examinations requiring higher- and lower-order cognitive skills, J. Chem. Educ., vol. 76, no. 1, p. 112 (1999).

DOI: $10.1021 / \mathrm{ed} 076 \mathrm{p} 112$.

[19] H. Herunata, R. R. Amayliadevi, H. R. Widarti, Analisis Keterampilan Berpikir Kritis Pada Indikator Memberikan Penjelasan Lebih Lanjut Materi Hidrokarbon, J-PEK (Jurnal Pembelajaran Kim.), vol. 5, no. 5, pp. 47-58 (2020).

[20] G. Nicoll, J. S. Francisco, An investigation of the factors influencing student performance in physical chemistry, $J$. Chem. Educ., vol. 78, no. 1, pp. 99-102 (2001). DOI: $10.1021 /$ ed078p99

[21] N. Entwistle, Teaching for Understanding at University, Deep Approaches and Distinctive Ways of Thinking. London, Palgrave Macmillan, 2009.

[22] M. B. Nakhleh, Are our students conceptual thinkers or algorithmic problem solvers - identifying conceptual students in general-chemistry, J. Chem. Educ., vol. 70 no. 1, pp. 52-55 (1993).

[23] S. Bailin, Critical Thinking and Science Education, Sci. Educ., vol. 11, no. 4, pp. 361-375 (2002). DOI: $10.1023 / \mathrm{A}: 1016042608621$

[24] U. Zoller, D. Pushkin, Matching Higher-Order Cognitive Skills (HOCS) promotion goals with problem-based laboratory practice in a freshman organic chemistry course, Chem. Educ. Res. Pract., vol. 8, no. 2, pp. 153171 (2007).

[25] N. S. Stephenson, N. P. Sadler-McKnight, Developing critical thinking skills using the Science Writing Heuristic in the chemistry laboratory, Chem. Educ. Res. Pract., vol. 17, no. 1, pp. 72-79 (2016) DOI: $10.1039 / \mathrm{C} 5 \mathrm{RP} 00102 \mathrm{~A}$.

[26] H. Habiddin, E. M. Page, Measuring Indonesian chemistry students' Higher Order Thinking Skills
(HOTS) in solving chemical kinetics questions, in Empowering Science and Mathematics for Global Competitiveness; Proceedings of the Science and Mathematics International Conference (SMIC 2018), 2018, pp. 215-222.

[27] C.-L. Chai, Enhancing visual literacy of students through photo elicitation, J. Vis. Lit., vol. 38, no. 1-2, pp. 120129 (2019).

DOI: 10.1080/1051144X.2019.1567071

[28] H. Habiddin, E. M. Page, Examining students' ability to solve algorithmic and pictorial style questions in chemical kinetics, Int. J. Sci. Math. Educ., 2020. DOI: $10.1007 / \mathrm{s} 10763-019-10037-w$.

[29] K. W. Whitten, R. E. Davis, L. Peck, G. G. Stanley, Chemistry, 10th ed. Belmont, Brooks/Cole, 2014.

[30] G. Tsaparlis, Higher and lower-order thinking skills: the case of chemistry revisited, J. Balt. Sci. Educ., vol. 19, no. 3, pp. 467-483, 2020.

DOI: https://doi.org/10.33225/jbse/20.19.467.

[31] E. O. Dincer, A. Osmanoglu, No title dealing with metric unit conversion: an examination on prospective science teachers' knowledge of and difficulties with conversion, Sci. Educ. Int., vol. 29, no. 3, pp. 174-182, 2019.

[32] K. Bain, M. H. Towns, A review of research on the teaching and learning of chemical kinetics, Chem. Educ. Res. Pract., vol. 17, no. 2, pp. 246-262, 2016.

[33] K. Bain, J.-M. G. Rodriguez, M. H. Towns, Zero-order chemical kinetics as a context to investigate student understanding of catalysts and half-life, J. Chem. Educ., vol. 95, no. 5, pp. 716-725 (2018). DOI: $10.1021 /$ acs.jchemed.7b00974

[34] J. K. Gilbert, On the nature of 'context' in chemical education, Int. J. Sci. Educ., vol. 28, no. 9, pp. 957-976 (2006). DOI: 10.1080/09500690600702470

[35] J. Kotz, P. Treichel, J. Townsend, Chemistry and Chemical Reactivity. Cengage Learning, 2011.

[36] R. Chang, K. A. Goldsby, Chemistry, Twelfth edition. New York: McGraw-Hill Education, 2016.

[37] J. E. McMurry, R. C. Fay, J. K. Robinson, Chemistry, 7th ed. United States of America, Pearson, 2016.

[38] T. E. Brown, B. E. Bursten, C. Murphy, P. Woodward, M. E. Stoltzfus, H. E. LeMay, Chemistry: The Central Science (13th edition). Pearson Education, Inc., United States of America, 2014.

[39] M. Hugerat, N. Kortam, Improving higher order thinking skills among freshmen by teaching science through inquiry, Eurasia J. Math. Sci. Technol. Educ., vol. 10, no. 5, pp. 447-454 (2014). DOI: 10.12973/eurasia.2014.1107a

[40] J. L. Jensen, M. A. McDaniel, S. M. Woodard, T. A. Kummer, Teaching to the test...or testing to teach: exams requiring higher order thinking skills encourage greater conceptual understanding, Educ. Psychol. Rev., vol. 26, no. 2, pp. 307-329 (2014). DOI: $10.1007 / \mathrm{s} 10648-013-9248-9$

[41] K. Kim, P. Sharma, S. M. Land, K. P. Furlong, Effects of active learning on enhancing student critical thinking in an undergraduate general science course, Innov. High. Educ., vol. 38, no. 3, pp. 223-235 (2013). DOI: $10.1007 / \mathrm{s} 10755-012-9236-\mathrm{x}$. 
